\title{
APUNTES ANTE UNA EVENTUAL REFORMA CONSTITUCIONAL EN MÉXICO
}

Fernando REY MARTÍNEZ*

En 1917, México asombró al mundo con un nuevo modelo de Constitución que se distinguía tanto de todas las anteriores, por su fuerte carácter social, como de las próximas que estaban a punto de surgir tras la Revolución rusa. La Constitución de Querétaro inaugura, pues, una tercera vía entre el viejo paradigma constitucional liberal-burgués y el emergente, también por esas mismas fechas, modelo de socialismo real. Y este nuevo modelo mexicano de constitucionalismo social se va a convertir, sobre todo por su influencia sobre las Constituciones alemana de Weimar (1919) y republicana española (1931), en un semillero fértil de sugerencias para el constitucionalismo democrático mundial posterior. El constituyente mexicano de 1917 supo convertir en gramática constitucional las nuevas realidades cambiantes del periodo en el que nació, un tiempo de aceleración de la historia. Supo leer la nueva realidad, anticipándose a otros.

La Constitución mexicana ha sido reformada en numerosas ocasiones, tantas que a veces resulta difícil identificar el texto vigente, pero desde algunos medios académicos y políticos se plantea ahora la posibilidad de aprobar un nuevo texto constitucional que abrogue la anterior y no simplemente la modifique de modo parcial, quizá haciendo coincidir este proceso con el centenario del documento inicial; como extranjero nada tengo que decir sobre el particular, ya que se trata de una decisión que, obviamente, sólo corresponde al pueblo mexicano. Como jurista constitucionalista sí me gustaría, sin embargo, aportar algunas reflexiones sobre este asunto.

\footnotetext{
* Catedrático de Derecho constitucional en la Universidad de Valladolid.
} 
Esta revista forma parte del acervo de la Biblioteca Jurídica Virtual del Instituto de Investigaciones Jurídicas de la UNAM

Concretamente, plantearé tres condiciones ideales, de carácter formal y procedimental y no de fondo, sobre las condiciones de una reforma constitucional ideal:

Primera. Hasta donde se me alcanza, el problema principal del constitucionalismo mexicano, en este punto, no sería el de aprobar un nuevo texto (aunque quizá podría ser una opción interesante), cuanto el de reforzar las garantías de su aplicación real por los actores políticos y los operadores jurídicos. Ciertamente, el problema no es sólo mexicano. Uno de los factores más inquietantes y extendidos del constitucionalismo comparado, en la actualidad, es la pérdida de densidad normativa de los textos constitucionales. Frente a esta tendencia, recordemos el hecho obstinado de que la Constitución sólo vale lo que valen sus garantías reales de aplicación. Una Constitución que no se aplica, o que se aplica sólo a veces o sólo en parte, hace perder crédito y legitimidad a todo el sistema político en un momento, por cierto, en que no anda precisamente sobrada de ellos.

Segunda. Otro factor a tener en cuenta es que las mayorías políticas del momento no deberían reformar a su libre capricho el texto constitucional porque éste, como es sobradamente conocido, establece las reglas del juego y no las reglas políticas estratégicas de corte coyuntural. El Ejecutivo de turno no puede ser el dueño de la Constitución, sino su servidor más leal. Esto significa, entre otras cosas, que un nuevo texto constitucional sólo debería aprobarse, en condiciones ideales, si se reúne un altísimo grado de consenso entre las fuerzas políticas mayoritarias.

Tercera. Un texto constitucional ideal debe regular sólo lo fundamental de la convivencia política y no todos los detalles de una materia, que deben remitirse a la ley y al reglamento. La Constitución mexicana vigente tiene alma de Constitución pero cuerpo de ley e incluso de reglamento. Sería óptimo, a mi juicio, que el eventual nuevo texto fuera corto (adelgazando, ganaría peso), accesible a los ciudadanos, ordenado y estar muy bien escrito, como corresponde a un país con una magnífica tradición cultural como es el mexicano. La Constitución no es un supermercado en el que cada individuo y grupo pueda satisfacer todas sus aspiraciones y necesidades. El constitucionalismo anglosajón siempre ha tenido claro que la misión esencial de la Constitución es controlar el poder, porque todo poder tiende a su abuso. Este principio de la sospecha no es, ni mucho menos, tan potente en la tradición cultural latinoamericana, donde el poder político es, en alguna medida, idolatrado. 
Esta revista forma parte del acervo de la Biblioteca Jurídica Virtual del Instituto de Investigaciones Jurídicas de la UNAM

Quizá se produzca aquí una secularización de la tradición cultural católica: el Estado vendría a sustituir a Dios en su papel de fascinante proveedor ilimitado de dones y gracias. El poder como un enorme sifón de premios y fondos. En este contexto, la idea de control del poderoso es mucho más débil. Por supuesto, no pretendería que el constitucionalismo latino se convirtiera en anglosajón; esto no sería posible, pero tampoco deseable porque también los anglosajones tienen sus problemas y porque el constitucionalismo latino debería ser menos dependiente de categorías e ideas ajenas, aunque, obviamente, deba tener en cuenta las aprovechables. Mas una cosa es que México no sea Londres, Nueva York u Otawa y otra muy distinta es que no exista también allí una noción fuerte de la idea de control político. Ninguna Constitución debe prometer lo que el Estado no puede dar.

En definitiva, si la reforma constitucional en México pretendiera alcanzar un texto más breve, claro, ordenado y realista, que estuviera por encima de los partidos políticos y de las mayorías del momento, que fortaleciera los mecanismos e instituciones de control político, gastando menos dinero, y, sobre todo, que se aplicara de verdad por los actores políticos y jurídicos, entonces sí se darían, a mi juicio, las condiciones formales y procedimentales óptimas. En este breve paper no puedo entrar a examinar aspectos de fondo, de contenido. Tuve oportunidad de hacerlo en relación con la reforma constitucional del estado de Cohauila de Zaragoza en su momento y fue una actividad desafiante como pocas. Pero la cuestión es: ¿podrá de nuevo México asombrar al mundo, esta vez en 2017, con un texto constitucional capaz de poner nombre, formal y materialmente, a las nuevas realidades cambiantes de nuestro mundo, que asiste a un cambio de época? ¿Podrá el constituyente mexicano estar a la altura del momento histórico para dar respuesta cabal a las viejas aspiraciones de libertad, igualdad y fraternidad que siguen siendo el GPS del constitucionalismo democrático? Sólo puedo decir, por último: ojalá. 